\title{
SELF-HEALING MATERIAL BACTERIAL CONCRETE
}

\author{
Ravindranatha $^{1}$, N. Kannan ${ }^{2}$, Likhit M. L ${ }^{3}$ \\ ${ }^{1}$ Assistant Professor - Selection Grade, Department of Civil Engineering, M. I. T - Manipal, Karnataka, India \\ ${ }^{2}$ Assistant Professor, Department of Biotechnology, M. I. T- Manipal, Karnataka, India \\ ${ }^{3}$ Students, Department of Civil Engineering, M. I. T - Manipal, Karnataka, India
}

\begin{abstract}
The requirement of high durability for structures exposed to harsh environment such as seafloor, offshore, tunnels, highways, bridges, sewage pipes and structures for solid, liquid wastes containing toxic chemicals and radioactive elements may not be achieved using today's ordinary portland cement $(O P C)$. This research gives information about the aims at increasing the strength and the total durability of the concrete used in the present day by introducing bacteria (Bacillus pasteurii). This micro organism is a soil bacterium. Bacillus pasteurii exhibits a phenomenon known as bio-calcification as a part of its metabolic activity. Bio-calcification is a process through which the micro-organsim externally secretes calcium precipitate, which in the presence of a carbonate ion forms $\mathrm{CaCO}_{3}$ which fills up the voids in the concrete texture thus making it more compact. This inturn improves the strength in concrete due to growth of the filler material within the pores of the concrete mixer. A comparison study was made with concrete cubes and beams subjected to compressive and flexural strength tests with and without the bacterium. It was found that there was high increase in strength and healing of cracks subjected to loading on the concrete specimens.
\end{abstract}

Keywords: Bacillus pasteurii, compressive strength, flexural strength, and Bio-calcification.

\section{INTRODUCTION}

\subsection{Cement}

Cement concrete is one of the most widely used construction material by mankind and it is the main material used for the infrastructure development of every country. Cement is a binder, a substance that sets and hardens independently, and can bind other materials together. Cement is generally graded according to a few set of specifications defined (those defined to IS 650:1996). which differentiate the various grades of cements. The most important factor considered for cement grading is the average compressing strength of the material in a given particular amount of time over a particular area in a particular composition of the cement mortar mixture. There was an increase in compressive strength of the cement with the use of the bacteria Bacillus pasteurii [6].

\subsection{Bacteria}

Bacteria are relatively simple, single celled organisms. The bacteria used were Bacillus pasteurii. It is a bacterium with the ability to precipitate calcium carbonate in the presence of any carbonate source [2]. The bacterium is used in this project for the same and for the improvement in the strengths of the concrete test specimens were observed. The microbes are a bacillus species and are completely not harmful to human beings. They precipitate inorganic crystals hence the healing of the cracks takes place in the concrete and it can withstand any temperature conditions.

\subsection{Problem Faced}

All RCC members are porous in texture in a microscopic scale. This porosity of building material allows moisture and water due to precipitation seep into the concrete members in time which causes cracks and thereby corrosion of steel reinforcements thus reducing the structural integrity and durability of the structure and at worst case scenario failure of the structure an additive that seals the pores and cracks and thus reduces the permeability of the structure would immensely improve its life. Conventionally, a variety of sealing agents such as latex emulsions and epoxies etc., and surface treatments with water repellents such as silanes or siloxanes are used to enhance the durability of the concrete structures. However, they suffer from serious limitations of incompatible interfaces, susceptibility to ultraviolet radiations, unstable molecular structure and high cost.

\subsection{Calcification}

Bacterial concrete, as the name suggest is an improvisation provided to cement using living microbes which are capable of doing so. Using microbes such as Bacillus pasteurii which as properties of bio calcification can secrete calcium carbonate as an extracellular product thus filling the pores and the cracks internally making the structure more compact and resistive to seepage. As the texture becomes more compact the compressive strength is also considerably increased. Thus, this process can reduce the seepage considerably permanently [3]. 


\section{PROCEDURE}

\subsection{Preparation of Bacterial Solution}

Primarily $12.5 \mathrm{~g}$ of Nutrient broth (media) is added to a $500 \mathrm{ml}$ conical flask containing distilled water. It is then covered with a thick cotton plug and is made air tight with paper and rubber band. It is then sterilized using a cooker for about 10-20 minutes. Now the solution is free from any contaminants and the solution is clear orange in colour before the addition of the bacteria [5].

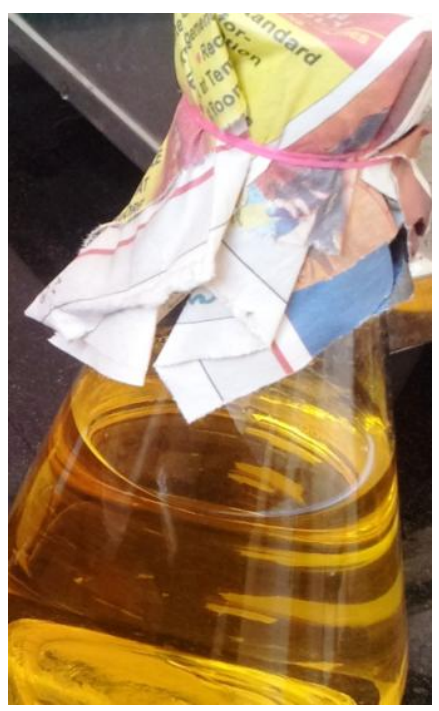

Fig -1: Solution without bacteria (only media)

Later the flasks are opened up and an exactly $1 \mathrm{ml}$ of the bacterium is added to the sterilized flask and is kept in a shaker at a speed of 150-200 rpm overnight. After 24 hours the bacterial solution was found to be whitish yellow turbid solution.

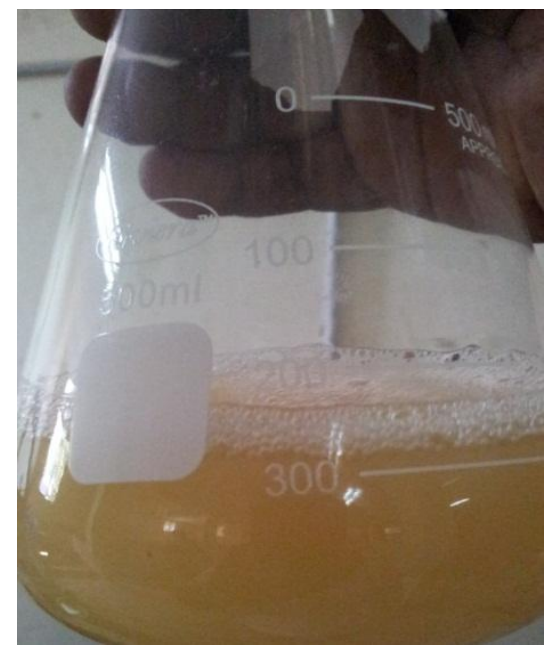

Fig -2: Solution with bacteria

\subsection{Compression Strength Test}

The cubical Moulds of size $150 \mathrm{~mm}$ x $150 \mathrm{~mm}$ x $150 \mathrm{~mm}$ were cleaned and checked against the joint movement. A coat of oil was applied on the inner surface of the Moulds and kept ready for the concreting operation. Meanwhile the required quantities if cement, fine aggregate and coarse aggregate (passing through IS sieve of $20 \mathrm{~mm}$ size and retained on 4.75 $\mathrm{mm}$ ) for the particular mix are weighed accurately for concreting. Fine aggregate and cement were mixed thoroughly in a hand mixer such that the colour of the mixture is uniform. Then, weighed quantity of coarse aggregate is added to the mixer and then it rotated till uniform dry mixture is obtained. Then, calculated quantity of bacterial solution and water was added and mixing was continued for about 3 to 5 minutes to get a uniform mix. The wet concrete is now poured into the Moulds and for every 2 to 3 layers and compacted manually. After concreting operations, the upper surface is leveled and finished with a mason's trowel. The corresponding identification marks were labeled over the finished surface and they were tested for 7 and 28 day strengths in a compressive strength testing machine [4].

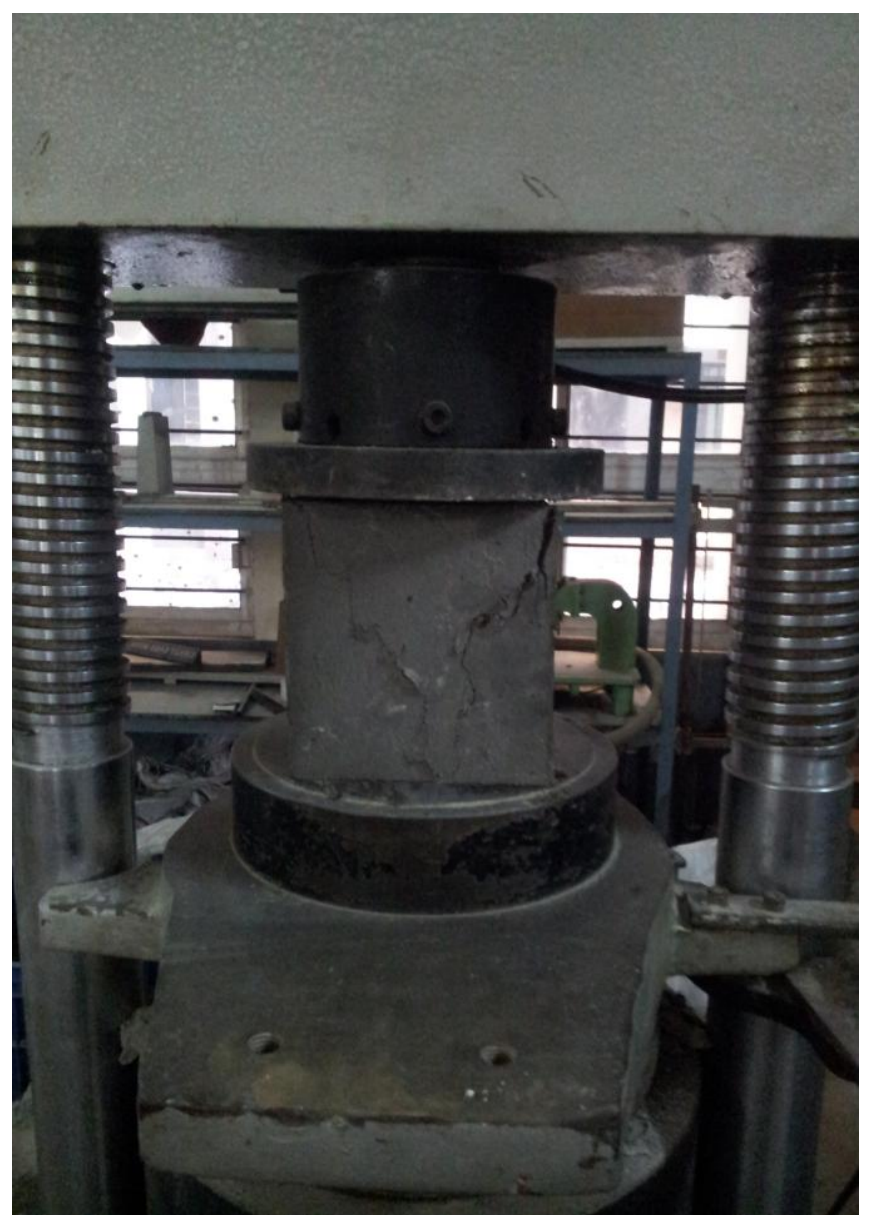

Fig -3: Concrete cube subjected to compression 


\subsection{Flexural Strength Test}

Moulds of $10 \mathrm{~cm} \times 10 \mathrm{~cm} \times 50 \mathrm{~cm}$ is used and the Moulds are cleaned and the joints between the sections of Moulds shall be thinly coated with Moulds oil and a similar coating of Moulds oil shall be applied between the contact surfaces of the bottom of the Moulds and the base plate in order to ensure that no water escapes during the filling. The interior faces of the assembled Moulds shall be thinly coated with Moulds oil to prevent adhesion of the concrete. Meanwhile the required quantities of cement, fine aggregate and corresponding coarse aggregate for the particular mix are weighed accurately for concreting. Fine aggregate and cement were mixed thoroughly in a hand mixer such that the colour of the mixture is uniform. Then, weighed quantity of coarse aggregate is added to the mixer and then it rotated till uniform dry mixture is obtained. Then, calculated quantity of water and bacterial solution was added and mixing was continued for about 3 to 5 minutes to get a uniform mix. The wet concrete is now poured into the Moulds in 2 to 3 layers and compacted manually. After concreting operations, the upper surface is leveled and finished with a mason's trowel. The corresponding identification marks were labeled over the finished surface and the beams were tested for 7 and 28 days strengths.

\section{RESULTS AND ANALYSIS}

The test results showed a significant difference in the specimens tested, with and without bacteria. Here are the following tables and charts which will give clear information about the compression and flexural strength test results.

Table -1: compressive strength test results for 7 and 28 days

\begin{tabular}{|l|l|l|l|}
\hline SI.NO & Days & $\begin{array}{l}\text { Normal } \\
\text { concrete } \\
(\mathrm{N} / \mathrm{mm} 2)\end{array}$ & $\begin{array}{l}\text { Bacterial } \\
\text { concrete } \\
(\mathrm{N} / \mathrm{mm} 2)\end{array}$ \\
\hline 1 & 7 & 20.84 & 27.09 \\
\hline 2 & 28 & 29.99 & 38.98 \\
\hline
\end{tabular}

Table -2: flexural strength test results for 7 and 28 days

\begin{tabular}{|l|l|l|l|}
\hline SI.NO & Days & $\begin{array}{l}\text { Normal } \\
\text { concrete } \\
(\mathrm{N} / \mathrm{mm} 2)\end{array}$ & $\begin{array}{l}\text { Bacterial } \\
\text { concrete } \\
(\mathrm{N} / \mathrm{mm} 2)\end{array}$ \\
\hline 1 & 7 & 3.92 & 4.6 \\
\hline 2 & 28 & 7.06 & 7.85 \\
\hline
\end{tabular}

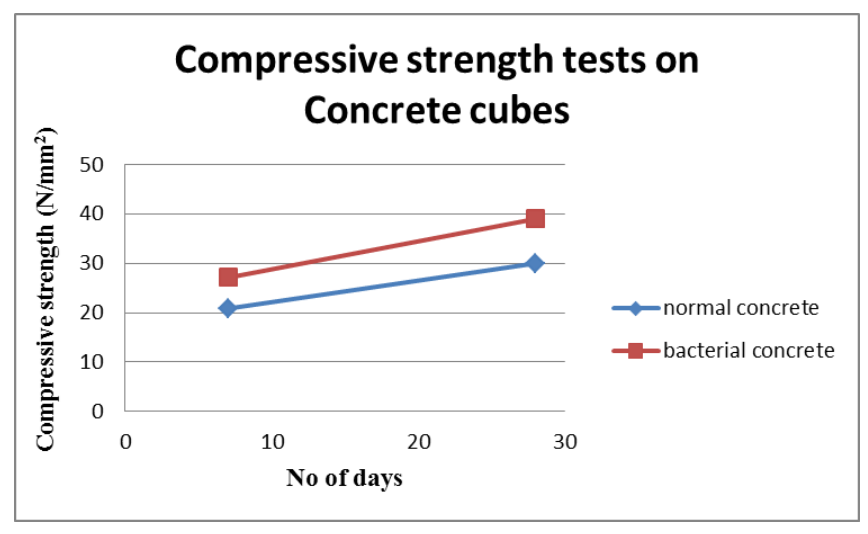

Chart -1: Comparison of compressive strength test results for 7 and 28 days.

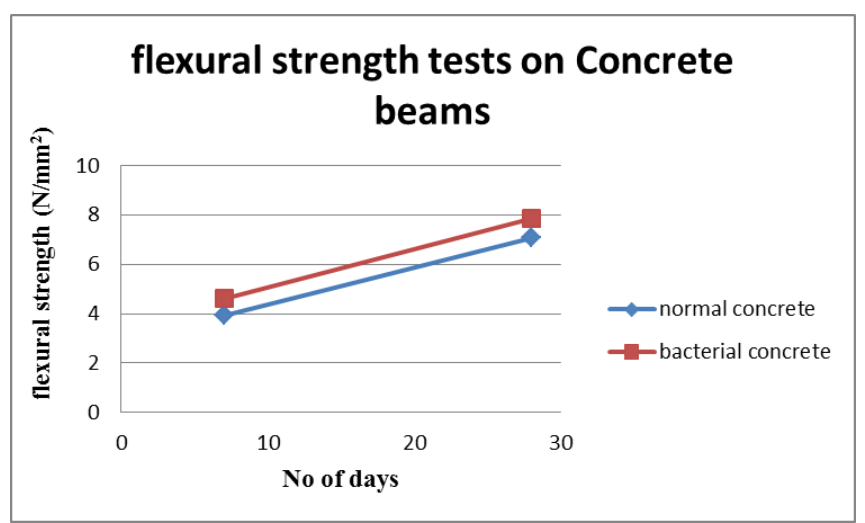

Chart -2: Comparison of flexural strength test results for 7 and 28 days.

\section{CONCLUSIONS}

The microbe proved to be efficient in enhancing the properties of the concrete by achieving a very high initial strength increase and thus we can conclude that the produced calcium carbonate has filled some percentage of void volume thereby making the texture more compact and resistive to seepage. When bacterial concrete is fully developed, it may become yet another alternative method to replace OPC and its hazardous effect on environmental pollution. Hence can be used for construction as it is resistant to corrosion as well [1].

\section{REFERENCES}

[1]. Abhijitsinh Parmar, Ankit Patel, Vismay Shah, Sandeep Khorasiya, Dipan Patel. (2013). "Improvement on the concrete cracks by using Bacillus pastuerii." International Journal for Scientific Research \& Development (IJSRD) | Vol. 1, Issue 1, 2013

[2]. Achal, V., Mukherjee, A., Basu, P . C., and Reddy, M. S. (2009). "Lactose mother liquor as an alternative nutrient source for microbial concrete production by Sporosarcina 
pasteurii." Journal of industrial Microbiology and biotechnology, 36, 433-438

[3]. Achal, V., Mukherjee, A., Basu, P . C., and Reddy, M. S. (2009). "Strain improvement of sporosarcina pasteurii for enhanced urease and calcite production." Journal of industrial Microbiology and Biotechnology, 36, 981-988.

[4]. Ghosh, P., Mandal, S., Chattopadhyay, B. D.,Pal, S. (2005). "Use of microorganism to improve the strength of cement motor." Cement and Concrete 'research, 35, 19801983

[5]. V. Achal; A. Mukherjee; and M. S. Reddy. 2010. Microbial Concrete: A way to enhance the Durability of Building Structures. J. Materials for Civil Engg.

[6]. Ramachandran, S. K., Ramakrishnan, V., and Bang, S. S. (2001). "Remediation of concrete using microorganisms" American Concrete Institute Materials J., 98, 3-9. 